\title{
Empirical Reasons, Theoretical Explanation, and Theoretical Framework on Why People Engage in Instant Justice
}

\author{
Edward Asafo-Adjei \\ Ediasfo-J Enterprise, Independent Researcher, Post Office Box 2393, Sunyani, Bono Region, Ghana
}

\begin{abstract}
The phenomenon of Instant Justice undermines human rights, the rule of law, and it is a concern for the development of democracy. Instant Justice is prevalent in many states especially in Africa, thereby generating research, intellectual discourse and public debate on the phenomenon. Instant Justice is of great concern therefore this paper aims to contribute to the intellectual discourse by providing understanding and explanation on the reasons why people engage in Instant Justice. The paper employs exploratory research methodology grounded in the use of desk research technique and a combination of trend and content analytical procedure. The paper is focused on achieving three objectives, the first, which is to review existing literature on some of the relevant empirical studies that have been conducted to determine the reasons why people engage in Instant Justice. It is further the objective of this paper, based on the empirical review and reasons established, to review relevant theories to provide theoretical explanation on why people engage in Instant Justice. Finally, it is the objective of this paper to develop a Theoretical Framework on Instant Justice using identified constructs from the empirical review and the theories reviewed. Significantly, the review of empirical literature, review of theories and Theoretical Framework developed provides reliable information that will equip state governments and other stakeholders to institute measures and structures to address the prevalence of Instant Justice. Again, the Theoretical Framework provides researchers with various identified constructs and how they correlate to enhance and guide further studies on Instant Justice.
\end{abstract}

Keywords: Instant Justice, Mob Justice, Vigilante Justice, Criminal Justice

DOI: $10.7176 /$ PPAR/11-4-02

Publication date:May $31^{\text {st }} 2021$

\section{Introduction}

Instant Justice is deemed to have occurred when people met out (on the spot) punishment to suspected criminals without the due process of the law (Bandewar, 2020; Attafuah, 2008). Instant Justice is the practice whereby an individual, a vigilante group and a mob takes the law into their hands in order to injure and kill a person or persons accused of wrongdoing (Adzimah-Alade et al., 2020; Asamoah, 2019; Gross, 2016; Ng'walali \& Kitinya, 2006; Silke, 2001).

In Instant Justice, the perpetrators punish suspected criminals in various ways. These include beating/lynching, roasting and burning. Roasting and burning are often done employing the "necklacing" method. The "necklacing" method of execution involves placing a petrol-filled tyre around the neck of the victim and then setting it ablaze (Adzimah-Alade et al., 2020; Minnaar, 1999). The petrol assists the tyre to burn fiercely. Beating is often carried out using whatever material is available at the moment of the act, and the materials often used include canes, stones, shoes, belts, and broken pieces of wood.

Various behaviours attract any or a combination of the forms of punishment. These behaviours include sorcery or magic, witchcraft, ritual murder, serial killing, hit-and-run driving, robbery and thievery (OtengAbabio et al., 2016; Yeboah-Assiamah \& kyeremeh, 2014; Schnoebelen, 2009; Sule, 2009). In the situation where the suspect is accused of stealing, the suspect is often beaten where all types of materials available on the spot is used. In cases where the victims are accused of crimes such as murder, rape, and armed robbery, the necklacing methods are often used as the last forms of punishments, usually after severe beatings. The methods used often result in the death of the victims or cause the victims to sustain severe injury.

No matter the crime committed or wrongdoing, it is the principal policy goal of the Criminal Justice instituted in States to ensure retribution or vengeance against the convicted criminal to reform or correct, rehabilitate or restore the convicted person to a life of normalcy (Maculan \& Gil, 2020; Daly, 2011; Bohm \& Haley, 2002; DiIulio et al., 1993). In view of this, the practice of Instant Justice deviates from the policy goal of Criminal Justice, because it focuses on punishment in the form of vengeance and does not seek to correct or rehabilitate. Moreover, Instant Justice only ensures that punishment is meted out to suspected criminal or wrong dowers without a right of appeal, or right to any of the formal protocols that ensure fair trial and justice (AppiahNyamekye, 2018; Kodah, 2012; Appiahene-Gyamfi, 1995).

Indeed, the Classical School of Criminology represented by Jeremy Bentham (1775) and Cesare (1764), refined and advocated the doctrine of proportionality in punishment. According to Bentham and Cesare punishment ought not to be proportional to the crime, and the harm caused. In that regard, a criminal is not supposed to lose his or her right to life if he or she had first deprived some victims of that right. Similarly, it will 
not be acceptable for a person whose mobile phone has been stolen, to execute the suspected mobile phone thief as a form of punishment. If he or she does so, then he or she becomes an unjustifiable murderer. The doctrine of proportionality also entails that sentencing must be similar to the punishments for the same type of offence in the Criminal Justice of a country. For instance, if a person is convicted for raping a ten-year-old girl, he should receive the same punishment as another person who was convicted for raping a ten-year girl under the same circumstances (Block, 2019; Hart, 1994).

The Criminal Justice System has been established in states to ensure that suspects or perpetrators of crime are brought to book, tried and punished in accordance with the laws of the land. In the Criminal Justice System, two elements are often significant to prove the culpability for a crime; the 'actus reus' and the 'mensa rea'. 'Actus reus' is the physical action constitutive of the crime, whereas 'mensa rea' pertains to the intentions of the criminal. Besides, the case must be established beyond reasonable doubt by the prosecutor for a judge to rule that the culprit has a case to answer.

It is accepted in penology that the sole body with an autonomous power to punish criminals is the state. The state performs this obligation through its various machinery and functionaries, all of which are embodied in the Criminal Justice System. Therefore, in any state where the Criminal Justice System exists, it becomes a problem when the individuals in such states decide to go behind the Criminal Justice System to punish persons suspected to have engaged in criminal activities. Such punishments given to suspected criminals outside the Criminal Justice System are often on the spot and have the propensity to affect human rights, undermine the rule of law, and serves as hindrance to the development of democracy in states.

This paper aims to contribute to intellectual discourse on Instant Justice by providing understanding and explanation on the reasons why people engage in Instant Justice. The paper is concentrated on achieving three objectives, the first, is to review existing literature on some of the relevant empirical studies that have been conducted to determine the reasons why people engage in Instant Justice. It is further the objective of this paper, based on the empirical review and reasons established, to review relevant theories to provide theoretical explanation on why people engage in Instant Justice. Finally, it is the objective of this paper to develop a Theoretical Framework on Instant Justice using identified constructs from the empirical review and the theories reviewed.

To achieve the aim and objectives set, the desk research approach or technique was employed to explore and source information from journals, books, newspapers, as well as online materials. Existing information in the form of relevant empirical findings and views/comments was analysed using both trend and content analyses. The use of trend and content analyses enabled relevant themes to be categorized, it paved room for empirical findings and views/comments to be summarized compared and discussed in a literature review fashion, made it easy for appropriate theories to be selected, and for relevant constructs or variables to be identified and categorized.

Significantly, this paper goes far to provide reliable information that will enable state governments, particularly those in Africa, and other stakeholders to understand Instant Justice and institute measures and mechanisms that will help curtail the canker. The Theoretical Framework developed will serves as fundamental policy guide and for further research on Instant Justice.

This paper is structured into five sections; it begins with the introduction section, followed by empirical review of the reason why people engage in Instant Justice, then the theories that explain Instant Justice, then the Theoretical Framework, and end with the conclusion.

\section{Empirical review on the reasons why people engage in Instant Justice}

The empirical review on why people engage in Instant Justice are covered under a selected number of themes which are: (1) decline in the level of confidence or trust in state authorities, (2) poverty, (3) corruption and delays in the Criminal Justice process, (4) low formal education attainment, (5) high crime rate and impunity in crime, (6) unemployment, (7) absence of state security, (8) political reasons. These themes are considered because they form significant tenants on why individuals, mobs and vigilantes take the law into their own hands (engage in Instant Justice). In subsequent sections, literature is reviewed on the themes.

\subsection{Decline in the level of confidence or trust in state authorities}

Trust keeps many individuals from violating promises and reduces the incidence of bribery and decrease cheating on rules which in turn reduces monitoring costs and allows for a more efficient society (Zak \& Knack, 2001). For there to be peace and order in the state, then, the people must not take the law into their own hands. This situation necessitates the need for the people to have a good collaboration with the state institutions which has been mandated by the law to ensure peace, security and justice. In this vein, trust becomes an indispensable factor to promote such collaboration.

A number of studies that have been conducted attribute the decline in the level of trust in state authorities to be one of the major reasons why people engage in Instant Justice (Bandewar, 2020; Adzimah-Alade et al., 2020; 
Asamoah, 2019; Neimark et al., 2019; Tankebe \& Asif, 2016; Nivette, 2016; Tankebe, 2013; 2009). Distrust in state law enforcement institutions, according to Zizumbo-Colunga (2010) increases levels of support for vigilante justice [Instant Justice] more strongly as levels of interpersonal trust increase. Where there is distrust in the very institutions in which people have trusted their wills to ensure their security, they become so frustrated and take up certain rights unlawfully which may undermine the rights and freedoms of others (Goldstein, 2003; Dimikov, n.d).

On the issue of trust, Tankebe and Asif (2016) established that persons who perceived the police as untrustworthy were more likely to endorse Instant Justice. Mistrust is motivated by police corruption, prolong police investigation, and misunderstanding of the justice system among the public, especially concerning the procedure of police bail where suspected culprits are temporarily released before the court process, and discontent in the criminal sentence given to convicted criminals (Adu-Gyamfi, 2014; Asare, 2007; Awuni, 2007). Adzimah-Alade et al., (2020) also affirms the motivating factors that has led to mistrust in the police and the Criminal Justice procedure, hence, recommends on the need to revisit the Criminal Justice administration and punishment procedures, as well as resource and empower the police to fight crime, including Instant Justice.

In South Africa, Harris (2001) comment that community mistrust in the state policing system and fear is explained to be among the cause of vigilante justice in South Africa. The Tanzania Human Rights Report (2007) published in 2008, supports distrust as a major cause of Instant Justice. The report outlined the claims of researchers from the Legal and Human Rights Centre (LHRC) that the number of mob justice incidents was increasing in Tanzania as a result of a lack of trust in the police. The report was supported by statements with both statistics from the Tanzanian police as well as the increased number of mob justice cases reported by the media during 2007. Again in Tanzania, it is a common view that police officers received bribes and released criminals instead of arresting them.

In Mexico, Binford (1998) remarked that a decline in the level of confidence in authorities in Mexico makes more Mexicans take the law into their own hands. The concept of the rule of law in a state as propounded by Dicey (1885) states that in all activities of the state, the law must rule. It is therefore not surprising that states prefer that citizens use official law enforcement institutions to resolve their differences, to seek protection, and to dole out retribution for crime (Donnelly, 2006). Where the state's ineffectiveness spreads to the realm of rule of law and it no longer has a monopoly over violence, communities may see collective violence (such as Instant Justice) as a moralistic response to deviant behaviour or the people will and may rely on their own strength to defend, to protect, and to act for caution against all other men (Metz \& Gaie, 2010; Randall, 2008).

Zizumbo-Colunga (2010) also conducted a study in Mexico and his findings affirmed that decline in the level of confidence in state authorities is a major reason why the Mexicans engage in Instant Justice. ZizumboColunga's study, concerning the principal variables used in what he called the model- interpersonal trust and confidence in state law enforcement, shows a significant interaction between trust in law enforcement institutions and interpersonal trust. Zizumbo-Colunga in his study raised some arguments worth acknowledging. The first part of his argument is that distrust in state law enforcement institutions increases levels of support for vigilante justice more strongly as levels of interpersonal trust increase. He backs this argument on the reason that citizens might be more willing to support the communal overriding of the official rule of law if they trust that their neighbours will act in their best interest. The second part of the argument is that the effect of interpersonal trust in support for Instant Justice is conditional on levels of confidence in state law enforcement. He further explains, by referring Consulta (2010) that the salience and pervasiveness of economic and security problems send a signal to citizens that the state lacks control in at least certain domains, including security and justice (Consulta, 2010 cited in Zizumbo-Colunga, 2010). Zizumbo-Colunga makes readers understand that this has resulted in some local communities excluding themselves from the protection of state authorities, thereby developing their forms of local controls as seen in Instant Justice.

\subsection{Poverty}

In his study: "Explaining Support for Vigilant Justice in Mexico", Zizumbo-Colunga (2010) again explained that the wealthier a person is, the less he or she will support people taking justice into their own hands. This finding of Zizumbo-Colunga is affirmative of the concept of stratification by Svanberg (2008), that is, poverty is a major cause of Instant Justice. He explains that poverty becomes a cause because the aristocratic nature of the judiciary subjugates the poor, and for such reason, personally punishing suspected criminals is mostly found appropriate by the poor peoples. The results of Zizumbo-Colunga's study, as he puts it, are supportive of Black (1976) hypothesis that wealth is negatively correlated with overriding the rule of law.

Handy (2002) also believes that poverty is one major reason why people engage in Instant Justice. In his article titled "The reasons for the spread of vigilante justice in contemporary Guatemala", he explained that the roots of such vigilante justice lies in a collapsing peasant economy, insecurity of all sorts, and the unraveled social fabric in rural communities through the militarization of rural Guatemala.

In states where the economies are on the verge of collapsing or has collapsed, it is not implausible that 
poverty would increase in those states. And such conditions propel Instant Justice. The case of Burundi is empirical support that poverty is a major reason for Instant Justice (Human Rights Watch, 2010). Outwater, Mgaya and Campbell (2013) agrees that poverty, and for that matter, the poor are the victims of Instant Justice in Tanzania, as the finding of their study reveal that most victims who suffered lynching and vigilante attacks in Dar es Salaam were unemployed, thieves, unknowns or street vendors. Chalya et al., (2015) also affirms poverty as a major cause of Instant Justice in Tanzania, especially in slum communities that are marginalized and deprived of socioeconomic development.

In Tanzania, Chalya et al., (2015) further affirmed in their study conducted between Augusts 2006 to June 2014 that the poor, the unemployed youth, and persons with low educational attainment who live in slum communities are the victims of Instant Justice. According to the findings, the median age of the victims was 28 years, and male victims outnumber the female on a ratio of $6.1: 1$.

Adinkrah (2005) also found in Ghana that the poor, unemployed or menially employed males are often the victims of mob or vigilante attacks and not the rich. Considering the findings of Chalya et al., (2015), Outwater, Mgaya and Campbell (2013) and Adinkrah (2005) it can be remarked that Instant Justice is discriminative, and such discrimination comes from the fact that it is the poor who are often mobbed and not the big-bellied, rich organised criminals who have the best security officials and yet their crimes (e.g., human trafficking, grand corruption and embezzlement) costs a lot to the society compared to petty crimes such as pickpocketing. Moreover, it can be said that inequality gap created between the rich and the poor, educated and uneducated, employed and unemployed, developed and deprived communities are the root causes of Instant Justice.

\subsection{Corruption and delays in the Criminal Justice process}

Corruption in the police and judges and the delays in the Criminal Justice System of states also explain why people engage in Instant Justice. In Ghana, for example, corruption has been explained as a cause of Instant Justice (Asamoah, 2019; Adu-Gyamfi, 2014; Attafuah, 2008). Corruption has made the people lose confidence in the police and the judiciary. Corruption in the judiciary is not seen only in terms of bribery, but a situation where the voice of the innocent goes unheard, while the guilty act with impunity. Corruption is not the only reason why the people have lost confidence in the police and the court system, but their delays in the process of administering justice is another reason accounting for this. In Ghana, the issue of delays in the Criminal Justice System is buttressed by the call made by the President of the Association of Judges and Magistrates of Ghana (AMJG), Mr. Justice J. B. Akamba (an Appeal Court Judge) on members of the Bar and police, on October 4, 2007, to work efficiently and speedily in handling criminal cases (Attafuah, 2008). In the Five-Year Strategic National Policing Plan of the Ghana Police Service (2010), the Ghana Police Service accepts the fact that the public has lost confidence in the police due to corruption imbedded in the Police Service.

A study conducted by Tankebe (2009) in Ghana makes us have a different understanding of the causes of Instant Justice. He concluded that Instant Justice stems from the perception of reduced fairness and equity rather than from the perceived ineffectiveness of policing. Tankebe's objective was to look for a relationship between citizens' perceptions of procedural justice in policing and whether there is resulting support for vigilantism in Ghana. Tankebe drew his idea of procedural justice from Tyler and expanded it, which he sought to see whether views regarding fairness and equity influence vigilante behaviour by citizens as a response to law enforcement practices. Tankebe considered to test four hypotheses: the first hypothesis was if citizens experience corruption and have perceptions of police ineffectiveness, they are more likely to support vigilantism; that the presence of citizen perceptions of procedural unjustness leads to an expression of support for vigilantism was the second hypothesis; the third hypothesis was that if citizens perceived the police as trustworthy, they would be less likely to support vigilantism. The last hypothesis was that individuals who achieved a higher level of education would be less likely to support vigilantism. The results from Tankebe's work did show that age, education, and police trustworthiness were the most significant predictors of support for Instant Justice. Again, he concludes that the impacts of procedural fairness were found to be embraced within police trustworthiness, but perceptions of police effectiveness and experience of police corruption were not statistically significant predictors of vigilante support. Tankebe collected his data in the summer of 2006.

Kanaabi (2004) for instance associates the causes of mob justice to a public perception of an ineffective judicial system. Kanaabi's work, "An assessment of the factors responsible for mob justice in the management of public affairs in Kampala District from 2004", had an emphasis on the problematization of constraints such as corruption and insufficient funds within the judicial institutions. According to him, this leads to public distrust against these institutions and mob justice becomes a vital alternative when it comes to solving judicial issues.

In Burundi, the study conducted by the Human Rights Watch (2010) explained corruption within the police service and the judiciary as one of the reasons why people engage in Instant Justice. Glad et al. (2010) also affirms this. They applied a qualitative methodological approach to their study. Their empirical results thematically explain that the judicial system emerges as one of the main causes of mob justice. They found that this was due to corruption and delays in the judicial system. Their empirical results moreover revealed that the 
police set bad examples for the public by not acting appropriately according to the Ugandan law. Similarly, their group discussions held revealed that the judicial and police officers are corrupt and this corruption keeps out a major part of the poor people in Uganda from reporting cases to the police and are unwilling to use the courts since they cannot afford to bribe certain officials.

Corruption breeds distrust in the state law enforcement agencies and institutions. Harris (2001) also conducted a study in South Africa and remarked that Instant Justice was frequently justified as 'filling a policing gap' due to police inefficiency, corruption and compliance with criminals. Ng' walali and Kitinya (2006) also affirms that corruption is one of the key reasons for mob justice in Tanzania.

\subsection{Low formal education attainment}

Low formal education attainment has been explained as one of the reasons why people engage in Instant justice. Here, the conclusion of Zizumbo-Colunga (2010) is similar to that of Glad et al. (2010), on the fact that persons from lower social classes are less likely to use the judicial system. This empirical fact supports the Anomie and the Concept of Stratification Theories of Dahrendorlf (1985) and Svanberg (2008) respectively.

According to Glad et al., (2010) persons from the lower classes do not feel part of the social community and the judicial system, and, therefore, distance themselves from the judicial system. They add that the lower social class is kept out by the structure of the judicial system. According to them, the uneducated in the lower social class is being ignorant of the law because they do not understand English since it is not their first language. The English language is the language mostly used in the courts in Uganda. For this reason, its use creates a huge language barrier.

\subsection{Impunity in crime}

Impunity has been identified and explained to be a cause of Instant Justice. Nalukenge (2001) examined the relationship between mob justice and its weaknesses in the Uganda judicial system and policing. Nalukenge collected data through qualitative interviews with both mob justice participants as well as general supporters of the phenomenon. Nalukenge also made use of questionnaires to collect data from public actors within the legal system of the Ugandan society. After his study, he concluded that the causes of mob justice are rooted in an insufficient legal structure where weak laws (and following punishment) do not match the impact of the crimes committed. Thereby people take the law into their own hands and met out punishments that will match the crimes committed. Glad et al. (2010) also conducted a study in Uganda, and they affirmed the findings of Nalukenge. However, they went further to remark that if certain crimes are not punished, it turns to create an arbitrary and unreliable judicial system. They explained that under any circumstances where the law enforcement is absent, the public will try to uphold the law themselves and create their sanctions.

The findings of Nalukenge (2001), Glad et al. (2010), and others that people take the law into their own hands and met out punishments that will match the crimes committed has been criticized by Friendly (2003). According to Friendly (2003), the degree of suffering involved with such punishment is incommensurable with criminal activity, culpability, and harm caused by the suspected criminal. Such punishment often leads to the death of victims and survivals require surgical treatment or wound debridement (Chalya et al., 2015). Further on the issue of punishment, it is argued that the perpetrators of Instant Justice exert the same punishments to juveniles, adults, recidivist imbeciles, and do not take into consideration mitigating factors such as age, first offenders, gender, and necessity.

The principle that punishment or penalties be proportionate in their severity to the gravity of the offender's conduct seems to be a basic requirement of fairness. However, in Instant Justice all crimes are treated alike and with the same severity, and it is contrary to the principle of proportionality which among other things presupposes a capacity to grade crimes according to their seriousness; that is, ranking crimes' gravity. Again, Rothbard $(1979$; 1998) makes it clear that the proportionate principle entails a maximum, rather than a mandatory punishment for the crime. According to McHugh (2008), it is from such a trend that many countries have promulgated "minimum sentencing laws" to ensure the severity of criminal penalties by placing crimes in a hierarchy.

\subsection{Unemployment}

Unemployment and prolonged economic hardship is a motivating factor for increasing crime rates perpetuated by the youth, and consequently causes Instant Justice for which the youth are often the perpetrators and the victims (Goldstein, 2003; Ng'walali \& Kitinya, 2006). Unemployment among the youth also explains Instant Justice. Baker (2005) posits that mob or vigilante justice incidents are mainly conducted by young men. Dahrendolf (1985) in his explanation of Anomie affirms this.

In Tanzania, Ng'walali and Kitinya (2006) and Outwater, Mgaya and Campbell (2013) provide empirical support that the youth are the perpetrators and victims of Instant Justice. Ng'walali and Kitinya investigated the magnitude of mob justice and its associated factors. Their research was based on mob justice cases in Dar es 
Salam during a period of five years (2000-2004). The materials and methods used include a four-year autopsy study, case information given by the police and interviews with witnesses, family members and friends of the deceased. The results from their study revealed that most people who died as a result of instant mob justice were the youth. Their study again revealed that the youth were the victims because the youth, in most cases, fail to achieve their goals and dreams such as employment and financial independence, and therefore resolve to commit crimes which result in high crime rates and more incidences of Instant Justice by the mob.

\subsection{Absence of state security}

The absence of adequate police posts or lack of police presence in most areas makes people easily engage in Instant Justice. The Tanzania Human Rights Report (2007) attributed this to be another cause for the increased mob justice in Tanzania. Kubende (2016) also affirms that the marginalized residents in informal settlements such as slums are rarely served by social institutions such as the police and justice system, hence the perceived indifference of such institutions in slum communities or informal settlements has led to the growth of community informal justice measures, which usually take the form of mob justice, meted out on people suspected of committing crimes, even petty ones. Slums or informal settlements are retreats for robbers, carjackers and other hardened criminals who commit crimes in the affluent parts of the city, yet victim's access to justice machineries is negligible (Kubende, 2016; Musoi et al, 2014). This factor was also revealed by Glad et al (2010) to be one among several causes that explained mob justice in Uganda. Glad et al. (2010) explained that as a result of the absence or inadequate police presence in remote areas, the people in some parts of the country were unable or found it difficult to report cases and, in the absence, mob justice became the means to punish criminals and also address the issue of crime.

\subsection{Political reasons}

Instant Justice in most situations has been politically motivated. In South Africa, Harris (2001) concluded that the causes of vigilante justice vary within time in South Africa. The results from his study show that in the pre1994 period, vigilante actions were defined by recourse to politics and political intention. He explained that vigilante justice was used as a response to violent actions conducted in support of the apartheid state, rather than those carried out against it. Similarly, in Ghana, there are records of Instant Justice which were predominant during the regime of the Armed Forces Revolution Council (AFRC), where bands of soldiers and civilians, sometimes unauthorized and amorphous, took the law into their own hands and dispensed with impunity a distorted version of popular justice to criminals (Attafuah, 2008). During the AFRC regime, instant justice was used as a measure to address the issue of corruption, which saw young soldiers, individuals or groups met out justice to persons suspected to be corrupt. Instant Justice in such a form took a political image.

According to Attafuah (2008), Instant Justice in Ghana worsened at the beginning of Ghana's long transition from military to civilian liberal democratic rule which saw the growth and observance of human rights issues. In Burundi, the situation was not different. The Human Rights Watch (2010) emphatically stated that mob justice was encouraged by politicians as a means to protect public security.

\section{Review of theories on why people engage in Instant Justice}

In the previous section, that is the empirical review, various constructs were identified that explain why people engage in Instant Justice. The constructs in chronological order is perceived as follow: (1) decline in the level of trust and confidence in the Criminal Justice system in the state; (2) increase in crime and deviance in state or communities; (3) frustration of people as a result of the development of point 1 and 2; (4) easy formation of mob and vigilante groups especially by the youth and their perpetration of attacks on suspected criminals with impunity; (5) Instant Justice and its consequences of injury and death to victims; (6) deprivation of human right and limitation to the rule of law. In this section, literature is reviewed in consideration to selected theories that help explain the identified constructs and their relationships in the phenomenon of Instant Justice. In furtherance, theories reviewed include the Anomie Theory (Dahrendorf, 1985), the Theory of Mob Sociology (Schweingruber, 2000), the Concept of Stratification (Svanberg, 2008), and the Frustration-Aggression Theory (Dollard et al., 1939). Such theories were considered because they have distinct features that help explain the constructs identified, or in other words why vigilante groups and mobs take the law into their hands and mete out justice by punishing suspected criminals or wrong doers.

\subsection{Anomie Theory}

The term Anomie was first introduced into modern social science by Durkheim (1897) in his book "Suicide" (Dahrendorf, 1985, 21). Anomie was modernized by Dahrendorf in his thirty-seventh series Hamlyn lectures "Law and order", where he considered the fundamental question posed for the social order of free countries by the decline in respect for the law. Dahrendorf describes Anomie as chaos or dissolution of values and principles. Although Dahrendorf acknowledges that the definitions and criteria of Anomie have been vague and sometimes 
conflicting, he posits that Anomie is a social condition where norms that govern people's behaviour have lost validity.

Anomie is a social condition that can give rise to many kinds of behaviour which can occur when a society undergoes radical changes. According to him, Anomie provides a background condition in which crime rates are high. He remarked that Anomie and crime is not causal, however, increasing crime rates are caused by the lower social class, the unemployed, and the youth. He further explained that Anomie is a social condition where the validity of norms and behavior are no longer guarded by a government or other institutions subsequently bringing uncertainty and unpredictability of individuals' way of behaving.

Dahrendorf (1985) explains that there are four features in modern society which when they occur can make people disobedient to the laws which govern them. He refers to these features as no-go areas. Three of these nogo areas are crucial to explaining why people engage in Instant Justice. The first of the features is where certain crimes are committed with impunity. According to him, if violations of norms are not sanctioned, or no longer sanctioned systematically, they become themselves systematically. In an Instant Justice situation, the first feature stated has an implication. That is, in a situation where there are laws, but people commit crimes and go scot-free, others would also refuse to give recognition to the law. For instance, the law requires that a suspected thief is to be brought to book, tried, and, where appropriate, punished by the mandated institutions when the law or the mandated institutions refuse to ensure such obligations, others would take it upon themselves to arrest and punish as they deem appropriate. On the other hand, the perpetrators of Instant Justice are supposed to be prosecuted for their conduct, something which when not done reflects a process of changing values which are translated by the public to be upheld by law, and so are encouraged to engage in the same conduct.

The second feature focuses on some negative behaviour of the police which leads to Anomie. In most states, it is the duty of the police to prevent and detect crime, apprehend offenders, and maintain public order and safety of persons and properties. Such duty of the police is not restricted to some particular areas but covers all areas which fall within the territories of the state. According to Dahrendolf (1985), there are some areas which the police deliberately and systematically avoid when performing their duties. Such areas include, but are not limited to, institutions or organizations such as markets and schools (such as universities). In such markets and universities, although there are available codes or regulations which ensure some form of order and discipline, they sometimes find it difficult to use their discipline codes. Any little act or behaviour incites public passion and creates the necessary atmosphere for social disorder. In such an atmosphere, some behaviour such as Instant Justice which is intolerable becomes tolerable. In Ghana, particularly, this explains why Instant Justice occurs in the Hall of residency in most University campuses (Amponsah-Manager 2011).

Another feature in modern societies which makes people disobedient and subsequently causes them to take the law into their hands is the failure on the part of the police and the court to see to it that those who are guilty of serious offences are arrested and prosecuted (Dahrendolf, 1985). It often occurs when breaches of the norms become sufficiently massive. This is often seen in a situation where crime is carried out in a collective nature such as by a mob. In such a situation, it becomes extremely difficult and sometimes impossible for an arrest to be made. Such a situation waters the ground for behaviors such as Instant Justice to easily thrive.

Dahendolf's Anomie theory contradicts the ideas and opinions of some scholars. To begin, Passas (1990) in his article "Anomie and corporate deviance" does not agree with Dahrendolf that the lower social class is solely responsible for deviance and crime in states. Passas argues that although contemporary societies are inherently conducive to anomic trends, such trends do not only bring about lower social class deviance and crime but also higher social class and corporate deviance. That is, both the higher and lower social class has concerns that has significant implication for social order.

In another aspect, Lacey (2008) does not agree with Darendolf on his view that impunity will necessarily result in social disorder or Anomia. According to Lacey, modern society has turned out to be so civilized that it gives no grounds for Anomie. Civilization according to lacey is seen in the scope and content of criminal law, the performance of Criminal Justice officials, public attitudes to crime, and the extent and intensity of the penal system which is the bedrock of democracy in most states. Lacey on his idea of civilization shares the comment made by Churchill in the House of Common, on July 25th, 1910, that the mood and temper of the public concerning the treatment of crime and criminals is one of the most unfailing tests of the civilization of any country (Churchill, 1910 cited in Lacey, 2008). He believes that there is always some level of calmness and respect for the law, dispassionate recognition of the rights of the accused, and even of the convicted criminal, such that the idea of social disorder as a result of impunity is rare.

Finally, Dahrendolf's attempt to establish a link between unemployment, crime, and disorder contradicts the view of Reiner (2000). According to Reiner (2000), there is no relationship between unemployment, crime, and disorder. Reiner in an attempt to provide a strong basis on the assertion referred to Box (1987) who successfully has summarized fifty research projects on the relationship between unemployment and crime. Box in the summary has this to say that

"the relationship between overall unemployment and crime is inconsistent. On balance, the 
weight of existing research supports there being a weak but nonetheless significant causal relationship. However, properly targeted research on young males, particularly those from disadvantaged ethnic groups, which considers both the meaning and duration of unemployment, has yet to be done" (Box, 1987: pp. 96-97).

\subsection{Theory of Mob Sociology}

Schweingruber (2000) explains how a law-sensitive crowd or group can turn out to become a law-breaking mob in his theory known as Mob Sociology. Schweingruber established the theory of Mob Sociology on the notion that all crowds can transform into law-breaking mobs. Much aware of what his critics would say he went further to warn that a crowd is not a mob, but it can become one because when individuals are absorbed in a crowd, they become controlled by what he calls 'crowd mind', therefore leading to violence and destructive behaviours. Schweingruber makes readers assume that there is a form of automatic connection between crowd and violence behaviour. Momboisse (1967) clears the doubt with the most persuasive comment on a mob's attitude that as tension mounts, individuals become less and less responsive to stimulation arising outside the group and respond only to influences from within the group itself. This process creates among members of the crowd an internal rapport, a kind of collective hypnosis, in which the individual loses his self-control and responds only to the dictates of the crowd as a whole. As individual loses critical self-consciousness; his or her ability to act in terms of cool and rational consideration for mob anonymity absolves him/her of individual responsibility.

Momboisse identifies four types of crowds that may transform into irate mobs. They include casual crowd, conventional crowd, expressive crowd, and hostile or aggressive crowd. In his explanation, the people in a casual crowd happen to be at a certain place purposelessly and not unified or organised. The people in a conventional crowd, on the other hand, are assembled for a specific purpose such as watching a game or play and have similar common interests. In an expressive crowd, the members are involved in expressive behaviours like dancing or singing which are not directed destructively. Finally, a hostile or aggressive crowd means an unorganised group of people willing to be driven into lawlessness, but it is hesitant because it lacks organisation, courage or unity of purpose (Momboisse, 1967). According to Momboisse (1967), the hostile or aggressive crowd is most likely to become a mob. Analysing Momboisse's study justifies why incidents of mob justice are common in areas such as the market, bus terminals, and lorry stations.

\subsection{The Concept of Stratification}

Svanberg (2008) in his Concept of Stratification explains why people may engage in Instant Justice, as well as points out whom the perpetrators are likely to be. According to him, how the society has been structured play a significant role to determine the behaviour of people. Social justice is not served when discrimination occurs or when the system is unfair. The Constitution, regardless of state, has the purpose of ensuring secure "justice for all'. Svanberg (2008) uses the concept of 'stratification', within the scientific discipline of Sociology of Law to problematize the efficiency of the judicial system. Svanberg explains the word stratification as the vertical difference between people, for example concerning social class, financial resources, and education level. The concept was used by Glad et al. (2010) to aid analyses of empirical results of their study.

According to Glad et al. (2010), the concept of stratification can be seen in four different steps. They explain that the judicial system grows with increasing stratification. That is, "the legal rules depend on the extent to which a society is stratified" (Svanberg, 2008, 94). The second step explains that a more complex society is more stratified and most often has an extensive judicial system. On the third step, Svanberg argues that the judicial system can be unfair because judges tend to treat people who belong to their social class differently from those from other social classes. Finally, Svanberg (2008) argues that people from the lower social classes are not using the judicial system in the same way as people from the higher social classes. Svanberg believes that this is so because wealthy people often have properties or inheritances which put them in a better position to be able to afford the judicial system. According to him, regardless of the issue, a wealthy person is always likely to use the judicial system. He argues that the people from the lower social classes do not see themselves as persons worthy of being taken seriously by the judicial system. For this reason, the people from the lower social classes such as the poor and persons with lower formal education attainment always tend to take justice into their own hands (Instant Justice) than to seek justice in the court of law.

Analysing the concept of stratification within Instant Justice will aid the conclusion that Instant Justice is a behaviour which is perpetrated by people from the lower social classes such as the poor and persons with a lower formal education background. Moreover, Instant Justice occurs because there is discrimination or unfairness in the Criminal Justice System. Svanberg (2008) and Dahrendolf (1985) both agree that the lower social class is solely responsible for deviance and crime in states. However, this position contradicts the position of Passas (1990) who do not believe in only lower social class deviance and crime but also higher social class and corporate deviance. 


\subsection{Frustration-Aggression Theory}

The Frustration-Aggression Theory was first developed by Dollard and his research associates (Dollard et al., 1939). The theory has been modified and expanded by scholars such Miller (1941) and Berkowitz (1962) to be the most common explanation for violent behaviour seeming from one's inability to fulfill his or her needs. Best (2006) used the theory to explain how and why violent conflict occur. According to Best (2006), people are likely to show aggressive behaviour when they are frustrated. As to how one can be frustrated, Best (2006) explained that frustration occurs when the legitimate desires of a person or a people is denied because of the way the state or society has been structured.

In this paper, the Theory is used to explain why Instant Justice is associated with violence and provoked by frustration. According to the Frustration-Aggression Theory, people are likely to show aggressive behaviour when they are frustrated. Such frustration in the case of Instant Justice may be caused by increasing crime and deviance in the state or community, and lack of trust and confidence in the Criminal Justice System. In other words, frustration occurs when the legitimate desires of a person or a people is denied directly or indirectly. Such desires may include right to a peaceful state or community devoid of crime and social deviance such as murder, rape, ritual killing and armed robbery, desire for a more efficient Criminal Justice System, and desire for the rule of law in a state.

Linked to theories such as the Concept of Stratification (Svanberg, 2008), and the Anomie Theory (Dahrendolf, 1985), and Theory of Mob Sociology (Schweingruber, 2000), the Frustration-Aggression Theory, perhaps explains why people may engage in violent behaviours such as Instant Justice in a state. That is, events such as unfairness in the Criminal Justice System, poverty, insecurity, crime with impunity, and increase in crime rates, are enough to frustrate a person for that person to show hatred and aggression, that is, violence art such as Instant Justice, upon the arrested of any suspect of a crime.

Indeed, however well the Frustration-Aggression Theory may aid the explanation of violent behavours like Instant Justice, it will not be too harsh to state that the theory tends to be biased and show fallacious reasoning by maintaining that there exists a causal relationship between frustration and violent behaviour. It is far from the truth as explained by the theory that once a person is frustrated then that person must necessarily show aggression by exhibiting some form of violent behaviour.

In whatever form one may want to subject the weakness of the Frustration-Aggression Theory to intellectual discourse, the position of the theory on violence as a necessary and sufficient consequence of frustration is to some level supported by theories such as the Biological Theory and the Physiological Theory. Both theories argue and support the view that human beings are inherently violent and at any day will resort to the use of violence when they feel frustrated, as in the situation of arresting and beating a suspected criminal whom is blamed directly or indirectly for frustrating their desires.

\section{Theoretical Framework for Instant Justice}

The Theoretical Framework developed draws on the strength of multiple theories reviewed and significant constructs or variables identified from empirical review conducted. It explains graphically the main variables and conceptual issues in Instant Justice that can be studied and their connections (Jabareen, 2009; Imenda, 2014). It further provides an emerging structure for data collection, data analysis, interpretation and synthesis of findings when adapted for research (Jabareen, 2009) on Instant Justice. 


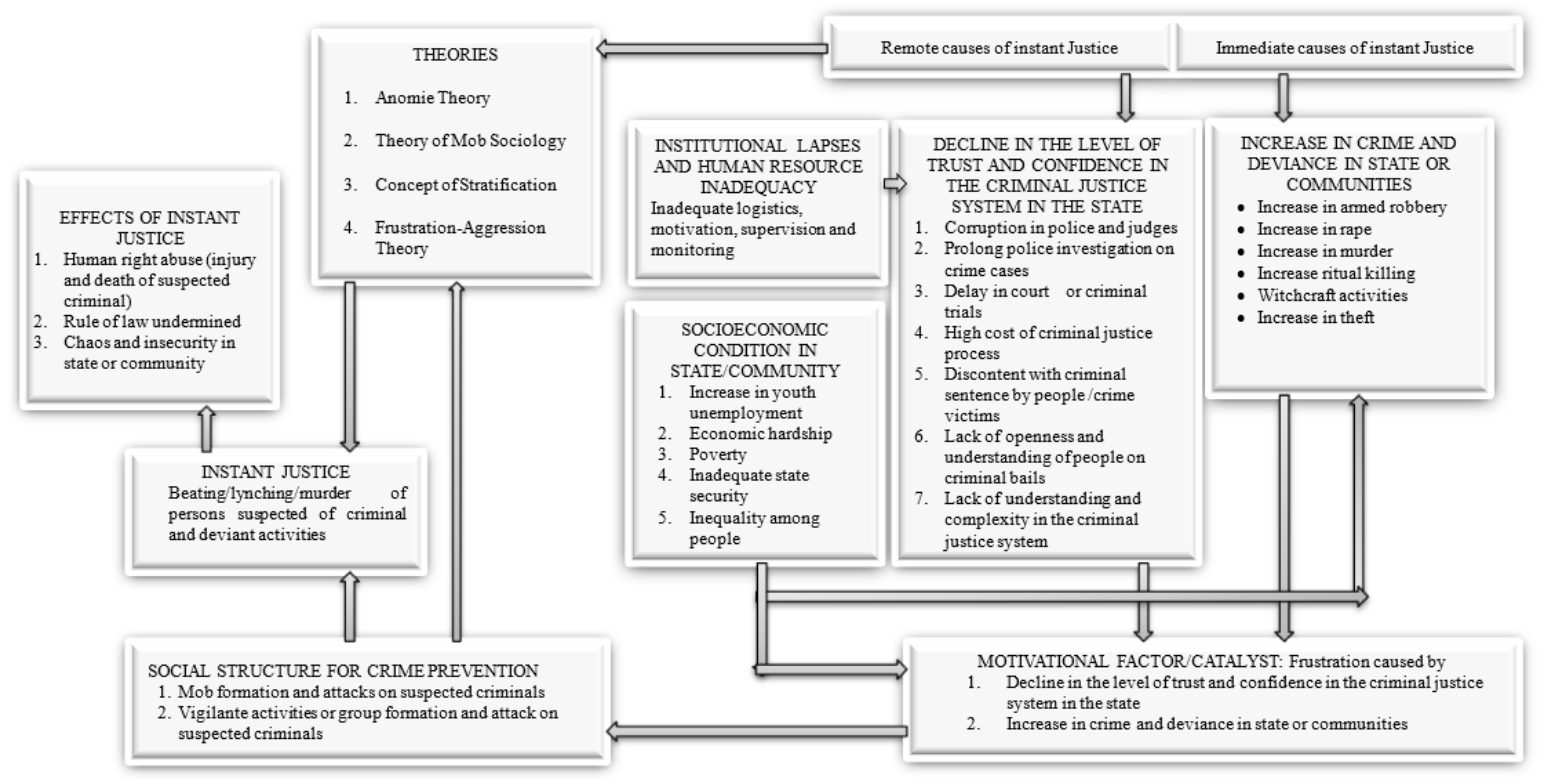

Figure 1: Theoretical Framework for Instant Justice

As indicated in the Theoretical Framework, Instant Justice is explained within the context of multiplicity of constructs or variable and sub-constructs and their interrelations.

The Theoretical Framework provides that Instant Justice has remote cause, which is as a result of decline in the level of trust and confidence in the Criminal Justice System. Such decline in the level of trust and confidence is due to various influencing sub-constructs which include but not limited to corruption in the police and judges, prolong police investigation on crime cases, high cost of Criminal Justice process or procedure, and discontent with criminal sentence by people or crime victims. The decline in the level of trust and confidence in the Criminal Justice System is influenced by factors like inadequate logistics, motivation, supervision and monitoring, which are sub-subject of institutional lapses and human resource inadequacy.

Increase in crime and deviance in states or communities is the immediate cause of Instant Justice. The persistency and records of crime and deviant behaviours such as rape, murder, theft, armed robbery, and witchcraft activities attract Instant Justice.

The remote and mediate causes alone although necessary are not a sufficient cause for Instant Justice unless it triggers frustration, which become a motivational factor or catalyst to the occurrence of Instant Justice. Frustration caused by the decline in the level of trust and confidence in the Criminal Justice System, and by increasing crime and deviance behaviours motivates or serves as catalyst to the formation and emergence of social structure for crime prevention, which registers in the form of mob formation and vigilante activities/group formation and attacks on suspected criminals (especially those caught in the act).

Mob formation and vigilante activities/group formation triggered by frustration drives the hunger and anger of people to engage in Instant Justice as explained by the Anomie Theory, Theory of Mob Sociology, Concept of Stratification and Frustration-Aggression Theory.

The beating/lynching and murder of suspected criminal and person who engage in deviate behaviours bleeds chaos in the state and security among people since anybody can become a victim, it undermine the rule of law, and inflicts on human rights.

\section{Conclusion}

The aim of this paper is to contribute to intellectual discourse by providing understanding and explanation on the reasons why people engage in Instant Justice. It is focused on achieving three objectives. The first objective is to review existing literature on some of the relevant empirical studies that have been conducted to determine the reasons why people engage in Instant Justice. The second objective is to review relevant theories to provide theoretical explanation on why people engage in Instant Justice. The third objective is to develop a Theoretical Framework on Instant Justice using identified constructs from the empirical review and the theories reviewed. The methodology used to achieve the aim and objectives is exploratory and it is grounded in the use of desk research approach, and trend and content analytical procedure. The paper successfully achieved its aim and objectives.

In reference to the first objective, review of literature on studies that have been conducted on Instant Justice highlights the fact that Instant Justice is not a new phenomenon as it has occurred in most countries throughout the world. Studies that have been conducted did show that there are diverse reasons which account for why 
people engage in Instant Justice. Some of the reasons do vary from one state or province to the other, whereas some overlap. Some of the reasons identified which also served as themes for the empirical review are decline in the level of confidence or trust in state authorities, poverty, corruption and delays in the Criminal Justice process, low formal education attainment, high crime rate and impunity in crime, unemployment, absence of state security, and political reasons. In view of the reasons identified and the facts establishing the reasons, this paper makes three suggestions:

1. The reasons why people engage in Instant Justices is based on multiplicity of interrelated factors which can be broadly classified as root causes and immediate causes. The root causes of Instant Justice may largely be classified into two as (1) institutional lapses and human resource inadequacy, and (2) decline in the level of trust and confidence in the Criminal Justice System. And (1) has a direct causal effect on (2).The decline in the level of trust and confidence in the Criminal Justice Systems is attributed to various reasons such as corruption in police and judges, prolong police investigation on crime cases, delay in court or criminal trials, discontent with criminal sentence by people/crime victims, lack of understanding and complexity in the Criminal Justice System, and high cost of Criminal Justice process. Factors such as inadequate logistics, motivation, supervision and monitoring explain why there is institutional lapses and human resource inadequacy.

2. The immediate causes of Instant Justice are the increase in various forms of crime and deviance such as rape, murder, and theft. Increase in crime and deviance is associated to unfavourable socioeconomic conditions in the state.

3. Instant Justice is mainly perpetrated by the youth in the form of mob and vigilante attacks.

To achieve the second objective, the Anomie Theory, the Mob Socialisation Theory, and the Concept of Stratification were reviewed to provide some explanations to the reasons why people engage in Instant Justice. The three theories mentioned do explain how and why people engage in Instant Justice in the form of mob and vigilante attacks. However, it appears that the issue of Instant Justice associated with hatred and intense violence is uncovered in the explanations of the three theories mentioned. Such lacuna is filled by the explanation from the Frustration-Aggression Theory. The Frustration-Aggression Theory explains that people engage in Instant Justice out of frustration which leads a person to express anger through violence. This paper therefore suggest that frustration serves as a catalyst to mob and vigilante attacks on suspected criminal and persons known or suspected to have engaged in deviant conducts.

The Theoretical Framework illustrates that Instant Justice has remote factors, immediate factors, catalytic factors, and occur within interplay of various diverse constructs or variables/factors. In view of this, any attempt by state governments and other stakeholders to address the prevalence of Instant Justice must concentrate on instituting measures and structures to address the remote and immediate factors. To remedy the remote and immediate factors, three policy directives are worthwhile, the first, must ensure providing adequate logistics motivation supervision and monitoring of institutions in the Criminal Justice System to ensure they work effectively and efficiently. There is the need for adequate police posts and courts to be established in marginalized or neglected communities to bridge accessibility gap. Again, the police service particularly in Africa should be resourced with modern technology and vehicles like helicopters to aid crime combat. The second is by making policies that will enable people develop trust and confidence in the Criminal Justice such as fast-tracking Criminal Justice processes and proceedings in courts, providing free and easily accessible legal aid and representation for persons, and establishing an outreach center to provide education to people on the Criminal Justice processes and proceedings. The third policy directive is for state governments to consider and implement social policy interventions targeted at reducing poverty and bridging all forms of inequality gaps related to people.

\section{References}

Adu-Gyamfi E. (2014): Implication of mob justice practice among communities in Ghana. Public Policy and Administration Research, 4(7), 87-96

Adinkrah M. (2005): Vigilante homicides in contemporary Ghana. Journal of Criminal Justice, 33(1), 413-427

Adzimah-Alade M., Akotia S. C., Annor F., \& Quarshie N., E. (2020): Vigilantism in Ghana: Trends, victim characteristics, and reported reasons. The Howard Journal, 59 (2), 194-213

Amponsah-Manager K. (2011). Suspected woman thief stripped naked by Legon students; Lawlessness Hall of Fame. Retrieved from http://www.talkafrique.com/issues/college-students-sexually-strip-naked-asuspected-woman-thief-molested on 24/4/2011

Appiahene-Gyamfi J. (1995): Alternatives to imprisonment in Ghana: A focus on Ghana's Criminal System. Thesis, Simon Fraser University: Canada.

Appiah-Nyamekye J. \& Armah-Attoh D. (2018): Ghanaians denounce mob justice and political party vigilantism, endorse rule of law instead. Afrobarometer Dispatch No. 186, February 2018.

Asamoah, D. (2019): Justice by the people's court: Mob action, vigilantism and the rule of law in Ghana. 
Conference Paper, Stockton University, New Jersey, United States of America

Asare K. S. (2007): Linking judicial inefficiency to mob justice, vigilantism and spiritual justice? The Statesmen, 30 July 2007; pp.7 \& 9

Attafuah A. K. (2008): Fighting Armed Robbery in Ghana. Ghana: The Justice and Human Rights Institute. Abjabery Road: Tudu, Ghana.

Awuni A. (2007): Mob Justice is a crime. The Mirror, P 35, General Assembly Resolution 49/184, 23 December 1994

Baker B. (2005): Multi-choice policing in Uganda. Police \& Society, 15(1), 19-41

Bandewar S. V. S. (2020): Public narrative on instant justice: A slippery slope. Indian Journal of Medical Ethics, 1(1), 3-6

Berkowiz L. (1969): Roots of aggression: A reexamination of the frustration-aggression hypothesis. New York: Atherton Press

Best G. S. (ed) (2006): Introduction to peace and conflict studies in West Africa: A reader. Ibadan: Spectrum Books Limited

Binford L. (1998): A failure of Normalization: Transnational Migration, Popular Justice and Police Repression in the contemporary neo-liberal Mexican social formation. Mexico: Oriente.

Black D. (1976): The behavior of law (1 ${ }^{\text {st }}$ Ed.). Academic Press

Block E. W. (2019): Libertarian punishment theory and unjust enrichment. Journal of Business Ethics, 154(1), 103-108

Bohm M. R. \& Haley N. K. (2002): Introduction to criminal justice ( $3^{\text {rd }}$ ed). Glenocoe/McGraw-Hill: United States

Box S. (1987): Recession, crime and punishment. Macmillan: London

Chalya L. P., Ngayomela H. I., Rambau F. P., Kahima J. K., Kapesa A. \& Ngallaba E. S. (2015): Mob justice as an emerging medico-legal, social and public health problem in North-Western Tanzania: a need for immediate attention. Tanzania Journal of Health Research, 17(1), 1-10

Dahrendorf R. (1985): Law and order. Sweet and Maxwell: London

Daly K. (2011): Aim of the criminal justice system. In Marmo M., Lint, W., and Palmer D., (eds) (2012): Crime and justice: A guide to criminology (4th edition). Sydney: Lawbook Co.

Dicey A. V., 1982 (1885): Introduction to the study of the law of the constitution, MacMillan and Co: London

Dilulio J. J., Alpert P. G., Moore H. M., Cole F. G., Petersilia J., Logan H. C., Wilson Q. J. (1993): Performance measure of the criminal justice system. Bureau of Justice Statistics: Princeton University

Dimikov R. P. (n.d): Why do people commit crimes? Theoretical models of criminal justice. Faculty of Philosophy, Department of Philosophical and Political Sciences: South-West University

Dollard J., Miller N., Doob L., Mowrer O., Sears R., (1939): Frustration and aggression. New Haven, CT, US: Yale University Press

Donnelly S. J. M. (2006). Reflecting on the Rule of Law: Its reciprocal Relation with Rights, Legitimacy, and Other Concepts and Institutions. The Annals of the American Academy of Political and Social Science, 603(1), 37-53

Friendly (2003): Punishment. Washington Times, 17 January 2003, p. A5

Gershoff T. E. (2010): More harm than good: A summary of scientific research on the intended and unintended effects of corporal punishment on children. Law and Contemporary Problems, 73(1), 31-56

Gershoff E. T (2010): More harm than good: A summary of scientific research on the intended and unintended effects of corporal punishment on children. Law and Contempt; Probs, 73, 31

Ghana Police Service (2010): Five-year strategic national policing plan. May 2010.

Glad R., Stromberg A., Westerlund A., Tikkanen R. (2010): Mob justice - A qualitative research regarding vigilante justice in modern Uganda. Thesis, University of Gothenburg

Goldstein D. (2003): In our own hands: Lynching, justice and the law in Bolivia. American Ethnologist, 30(1), $22-43$

Gross M. (2016): Vigilante violence and forward panic in Johannesburg's townships. Theory and Society, 45(3), 239-263

Handy J. (2002): Chicken thieves, witches, and judges: Vigilante Justice and customary law in Guatemala. Journal of Latin American Studies, 36(3), 533-561

Haris B. (2001): As for violent crime that's our daily bread: Vigilante justice during South Africa's period of transition. Violence and Transitional series, Vol. 1, Centre for the study of violence and reconciliation

Harris B. (2001): As for violent crime that's our daily bread: Vigilante violence during South Africa's period of transition. ISS Monographs, 1(1), 1-89

Hart H. L. A. (1994): The concept of law. Oxford: Clarendon Press

Human Rights Watch (2010): Mob justice in Burundi - Official complicity and impunity. Human Right Watch: 
New York

Imenda S. (2014): Is there a conceptual difference between theoretical and conceptual framework? Journal of Social Science, 38(2), 185-195

Jabareen Y. (2009): Building conceptual framework: Philosophy, definition and procedure. International Journal of qualitative Methods, 8(4), 49-62

Kanaabi M. (2004): An assessment of the factors responsible for mob justice in the management of public affairs in Kampala District. Makerere University, Kampala

Kodah K. M. (2012): Impact of mob [in] justice on the rule of law in Ghana. Munich, GRIN Verlag

Kubende S. H. (2016): Factors influencing crime in the urban informal settlement; a case study of Kibra. Research Project, Faculty of Arts - Department of Sociology and Social Work: University of Nairobi

Lacey N. (2008): The prisoners' dilemma: Political economy and punishment in contemporary democracies. Cambridge University Press: United Kingdom

McHugh T. J. (2008): Utilitarianism, punishment, and ideal proportionality in penal law: Punishment as an intrinsic evil. Journal of Bentham studies, 10(1), 1-16

Maculan E. \& Gil G. A. (2020): The rationale and purpose of criminal law and punishment in traditional contexts. Oxford Journal of Legal Studies, 40(1), 132-157

Metz T. \& Gaie J. B. (2010): The African ethics of Ubuntu/Botho: Implications for research on morality. Journal of Moral Education, 39(3), 273-290

Miller N. (1941): The frustration aggression hypothesis. Psychological Review, 48(4), 337-342

Minnaar A. (1999): The new vigilantism in Post-April 1994 South Africa: Crime prevention or an expression of lawlessness?, Paper presented at the CRIMSA International Conference: Crime prevention in the new millennium. Arendsnes, Cintsa East, East London, 25-28 May 1999

Momboisse R. (1967): Riot, revolts and insurrections. Springfield, IL: Charles C Thomas Publishers

Musio K., Muthama T., Kibor J. \& Kitiku J. (2014): A study of crime in urban slum in Kenya: The case of Kibra, Bondeni, Manyatta and Mishomoroni slums. Security Research Information Centre: Nairobi-Kenya

Nalukenge H. A. (2001): The right to life - a case study of the mob justice system in Uganda. Makerere University, Kampala

Neimark B., Osterhoudt S., Blum L., Healy T. (2019): Mob justice and civilized commodity. Journal of Peasant Studies 1-20

Ng' walali M. P. \& Kitinya N. J. (2006): Mob Justice in Tanzania: a medico-social problem. African Health Science, 6(1), 36-38

Nivette A. E. (2016): Institutional ineffectiveness, illegitimacy, and public support vigilantism in Latin America. Criminology, 54(1), 142-175

Oteng-Ababio M., Owusu G., Wrigley-Asante C., \& Owusu A. (2016): Longitudinal analysis of trends and patterns of crime in Ghana (1980-2010): a new perspective. African Geographical Review, 35(3), 193-211

Outwater H. A., Mgaya E., \& Campbell C. J. (2013): Community violence in Dar es Salaam, Tanzania: A mixed methods study. African Safety Protection Journal, 11(1), 25-38

Passas N. (1990): Anomie and corporate deviance. Contemporary Crises, 14(1), 157-178

Randall C. (2008): Violence: A micro - sociological theory. New Jersey: Princeton University Press

Reiner R. (2000): Crime and control in Britain. Sage

Rothbard M. N. (1973): For a new liberty. New York: Macmillan

Rothbard M. N. (1998) [1982]: The ethics of liberty. New York: The New York University Press

Schnoebelen J. (2009): Witchcraft allegation, refugee protection and human rights: a review of the evidence. Research Paper No. 169, Geneva, Switzerland: UNHCR, Policy Development and Evaluation Service

Schweingruber D. (2000): Mob sociology and escalated force: Sociology's contribution to repressive police tactics. Sociological Quarterly, 41(3), 371-389

Senechal de la Roche R. (1996): Collective violence as social control. Sociological Forum, 11(1), 97-128

Silke A. (2001): Dealing with vigilantism: issues and lessons for the police. The Police Journal, 74 (2), 120-133

Sule S. A. (2009): Is crime rate increasing in Ghana? Retrieved from http://www.ghanadot.com/news.ghanadot.sule0519091.html

Svanberg J. (2008): Rattssociologi: en introduction. Lund: Studentliterature

Tankebe J. \& Asif M. (2016): Police legitimacy and support for vigilante violence in Pakistan. International Journal of Comparative and Applied Criminal Justice, 40 (4), 343-362

Tankebe J. (2009): Self-help, policing, and procedural justice: Ghanaian vigilantism and the rule of law. Law \& Society, 43(2), 245-270

Tankebe, J. (2013): Viewing things differently: the dimension of public perception of police legitimacy. Criminology, 51 (1), 103-135

Tanzanian Human Rights Report 2007 (2008): Legal and Human Rights centre, Dar es Salam.

Tappan P. W. (1960): Crime, Justice, and Correction. New York: McGraw-Hill Series in Sociology 
Taslitz E. A. (2003): Daredevil and Death Penalty. Ohio State Journal of Criminal Law, 1 (1), 699 The Tanzania Human Rights Report (THRR), (2007): Legal and Human Right Centre, Dar es Salam

Yeboah-Assiamah E. \& Kyeremeh A. T (2014): A critical assessment of public administration and civil disobedience in Developing African Democracies: An international analysis of mob justice in Ghana. Journal of Law, Policy and Globalization, 28(1), 1-12

Zak J. P. \& Knack S. (2001): Trust and growth. The Economic Journal, 111(470), 295-321

Zizumbo-Colunga D. (2010): Explaining support for vigilante justice in Mexico. Latin American Public Opinion Project, AmericasBarometer Insights Series No. 39 